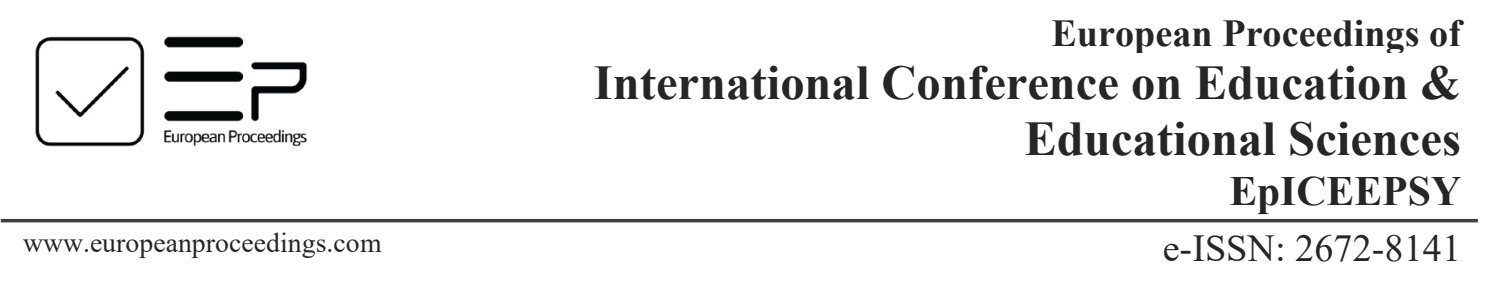

DOI: $10.15405 /$ epiceepsy.20111.28

$11^{\text {th }}$ ICEEPSY 2020

The International Conference on Education and Educational Psychology

\title{
INSTITUTIONALIZATION AND AUTONOMY IN ADOLESCENTS AND YOUTH
}

Liliana Oliveira (a), Rosina Fernandes (b)*, Emília Martins (c), Francisco Mendes (d), Patrícia Araújo (e)

*Corresponding author

(a) CEERIA - Centro de Educação Especial, Reabilitação e Integração, Alcobaça, Portugal, lilsgo@hotmail.com

(b) Escola Superior de Educação e CI\&DEI - Instituto Politécnico de Viseu, Viseu, Portugal, rosina@esev.ipv.pt

(c) Escola Superior de Educação e CI\&DEI - Instituto Politécnico de Viseu, Viseu, Portugal, emiliamartins@esev.ipv.pt

(d) Escola Superior de Educação e CI\&DEI - Instituto Politécnico de Viseu, Viseu, Portugal, fmendes@esev.ipv.pt (e) ISMAT - Instituto Superior Manuel Teixeira Gomes, Portimão, Portugal, pattaraujo@gmail.com

\begin{abstract}
The development of autonomy is influenced by different individual and contextual variables, that include socio-demographic and family/institutional (in cases where children live in residential care) background. Hence, the role residential care play in the process of providing children and youth at risk/danger with the adequate skills to prepare them to have an independent adult life is fundamental. A quantitative exploratory study was thus developed to characterize adolescents/young people autonomy (68.8\% living in residential care) and to explore individual variables relevance in this area. Most of the participants lived in coastal areas of the country $(69 \%)$, were female $(76.2 \%)$ and age ranged between 13 and $24(17.38 \pm 2.33)$. They completed the Autonomy Questionnaire for Adolescents. SPSS IBM 24 was used for data analysis and statistically significative differences were found $(\mathrm{p}<.05)$ : i) between males (with higher results) and females; ii) in functional autonomy according to age (higher scores among the 13-17 year-old group vs. 1824); iii) in functional and total autonomy, better in those living in residential care. These results stress the importance of investing in parental education initiatives that may foster the construction of youths' autonomy in their own families considering the role played by gender and age in intervention.
\end{abstract}

2672-8141 C 2020 Published by European Publisher.

Keywords: Adolescents/youth, autonomy, residential care, socio-demographic variables. 


\section{Introduction}

Children's rights promotion and protection is a recent achievement in human history. As a matter of fact, the Declaration of the Rights of the Child, adopted in an extended form by the United Nations in 1959, following the publication of the Universal Declaration of Human Rights in 1948, came about to guarantee children well-being, given the devastating effects of World War II on human rights (Oliveira, 2016).

In fact, today children are full human beings in their own right and should be, at least, granted the same rights as anyone else. We seek to ensure, through legal regulations, that this fundamental guarantee is respected. In Portugal, when these rights are compromised and the child is in danger due to parental abandonment, child neglect, physical or psychological abuse, sexual abuse, or due to other circumstances that may jeopardize the child's adequate development, protection measures are activated to ensure the child's best interests. These measures, provided for in Law $n^{\circ} 142 / 2015$, dated 8 September (revision of Law n $147 / 99$, dated 1 September) the "Lei de Proteção das Crianças e Jovens em Perigo (LPCJP)", the Portuguese children protection act, include, among others, residential care that should be temporary and promote the child's development, in all its dimensions, including autonomy (Delgado \& Gersão, 2018). These authors stress that it is essential that residential care institutions are able to promote skills that will enable young people to take individual responsibility for their life and make informed decisions for themselves, developing strategies that will allow them to be an independent adult life outside the institution.

Despite the $8 \%$ decrease in the number of children and young people living in residential care in Portugal in 2017, compared to the previous year, the latest CASA Report points out that 7553 of the 10410 identified children and youth are currently in such a situation (Instituto da Segurança Social, 2018). The same report states that 2857 children and young people have left residential care and that $7 \%$ of them are taking the first steps towards independent living.

It is therefore essential that residential care guarantee a safe environment to ensure development and empowerment, especially for young people who are unable to return to their family environment and have to stay longer in an institution. This is crucial to stimulate and develop personal and social skills that will prepare them to be full independent and autonomous (Instituto da Segurança Social, 2018). Some studies highlight this crucial role of residential care institutions in promoting autonomy (Silva et al., 2019). Costa et al. (2015) and Bailey et al. (2019) stress the role played by all the people who work at these institutions. Based in trusting relationships, staff should focus on personal, socio-affective, instrumental and behavioural dimensions to promote these young people's autonomy (Seth-Purdie, 2019).

In fact, the autonomy construct, understood as the capacity to become independent from others (Serdiuk et al., 2018), involves different dimensions. This developmental task, of paramount importance in adolescents, includes, according to the literature, three facets: emotional, cognitive and behavioral/functional. The cognitive or attitudinal dimension refers to decision-making skills, selfdetermination, self-assessment, setting personal goals, in short, with what the adolescent wants to do with his/her own life (Bernal Romero et al., 2020; Graça et al., 2010; Noom, 1999; Oliveira, 2016). According to the same authors, emotional autonomy refers to independence from parents and peers, to the process through which children or adolescents will assume their own personality and trust their own goals, beliefs and personal values, while respecting those of others. Finally, the authors add the ability to regulate our own behavior, to deal with external pressure and define strategies to achieve our own personal goals, related 
to the functional or behavioral dimension. Several personal and contextual variables play a crucial role in the process through which children and adolescents will develop the different dimensions of their autonomy.

When focusing on gender differences, those variances are nowadays less important than they were in the past. In fact, male and female show autonomous behaviors at different stages of their adolescence, however, this gender equality is not evident in all cultural contexts (Dutra-Thomé et al., 2019). It should also be noted that the studies conducted so far are not yet able to provide a consensus on the relevance of this variable in autonomy development. For example, Sher-Censor (2015) points higher autonomy levels in girls, contrary to Graça et al. (2010), that stress better results obtained by male respondents.

Research results are more coherent when it comes to age. Several studies (Graça et al., 2010; DutraThomé et al., 2019) point out that older adolescents exhibit better levels of autonomy, as expected.

The adolescents/young adults' social context also has a strong influence on their autonomy levels (Wood et al., 2018). The families' socioeconomic conditions (Barbosa et al., 2017) as well as the kind of work carried out in residential care to promote autonomy, have a strong impact on youngsters (Cabral, 2017), specially through evidence-based programs such as the Umbrella Program, one of the most popular and widespread in Portugal (Del Valle \& Quintana, 2006).

\section{Problem Statement}

As we have seen previous, the autonomy development is influenced by individual and contextual variables, including sociodemographic and family or, in its absence, institutional support. In this sense, the role of residential care institutions in preparing children and young people at risk for independent adult life is crucial.

\section{Research Questions}

In our study we looked for answers to the following two questions:

\subsection{Question 1}

What is the autonomy level of adolescents living with their families or in institutions?

\subsection{Question 2}

What's the relevance of sociodemographic and institutional variables in autonomy level?

\section{Purpose of the Study}

We developed our research to assess adolescent's/youth's autonomy level (including participants from residential care institutions), exploring the relevance of individual variables, such as gender and age, as well as institutional support, to outline interventions with individual specificities, for families or residential care professionals, both responsible for facilitating youth's adaptive transition to independent adult life. 


\section{Research Methods}

An exploratory study was developed, using quantitative methodology and an ex-post-facto design, to understand the influence of institutional care and socio-demographic variables on the autonomy of adolescents/young people.

\subsection{Participants}

The convenience sample (Table 01) included 42 adolescents/young people coming from several Portuguese districts, especially from the coastal area of the country $(69 \%)$. The majority $(n=29)$ were living in institutional care and 13 with their families. The participants, mostly female $(76.2 \%)$ were aged between 13 and 24 years $(17.38 \pm 2.33)$.

Table 01. Sample characterization

\begin{tabular}{|l|l|l|l|l|l|l|}
\hline \multirow{2}{*}{$\begin{array}{l}\text { Socio-demographic } \\
\text { background }\end{array}$} & \multicolumn{2}{|l|}{ In institutional care } & \multicolumn{2}{l|}{ Living with their families } & \multicolumn{2}{l|}{ Total } \\
\cline { 2 - 7 } & $\mathbf{n}$ & $\mathbf{\%}$ & $\mathbf{n}$ & $\mathbf{\%}$ & $\mathbf{n}$ & $\%$ \\
\hline Gender & 7 & 24.2 & 3 & 23.1 & 10 & 23.8 \\
Male & 22 & 75.8 & 10 & 76.9 & 32 & 76.2 \\
Female & 29 & 100 & 13 & 100 & 42 & 100 \\
Total & & & & & & \\
\hline Region & 10 & 34.5 & 3 & 23.1 & 13 & 31 \\
Interior & 19 & 65.5 & 10 & 76.9 & 29 & 69 \\
Coastal & 29 & 100 & 13 & 100 & 42 & 100 \\
Total & $\mathrm{Min}=13$ & $\mathrm{Min}=15$ & & $\mathrm{Min}=13$ \\
\hline Age & $\mathrm{Max}=22$ & $\mathrm{Max}=24$ & $\mathrm{M}=24$ \\
& $\mathrm{M}=17.2$ & $\mathrm{M}=17.69$ & $\mathrm{M}=17.38$ \\
& $\mathrm{DP}=2.44$ & $\mathrm{DP}=2.10$ & $\mathrm{DP}=2.33$ \\
\hline
\end{tabular}

\subsection{Instruments}

In addition to the ad hoc general background questionnaire, with socio-demographic and institutional questions, Noom's (1999) Autonomy Questionnaire for Adolescents (AQA), in its Portuguese version, created by Graça et al. (2010), was used. The instrument consists of 15 items, and uses a Likert scale $(1=$ nothing to do with me to $5=$ everything to do with me), organized in three different subscales: cognitive autonomy (items 1,4 and 9), which refers to the ability to make decisions and set goals independently; emotional (items 5, 11 and 13), that relates to how confident young people feel of their beliefs and personal values, without depending on social validation; and functional (items 2, 3, 7, 8, 10, 12 , 14 and 15), which is young people's ability to adopt a confident and self-determined conduct, and their capacity to launch activities and projects independently, without seeking approval from others (Graça et al., 2010). In the adaptation study for Portuguese population, the instrument revealed good psychometric qualities and four dimensions emerged in the factorial analysis: two (independence and self-determination) are associated with functional autonomy and the others with emotional and cognitive autonomy. In our study, we maintained the original structure, which follows the tripartite theoretical model on which it is based. 


\subsection{Procedure}

Once permission from the instrument authors was obtained, the adolescents/young people were contacted through a social network virtual group, set up specifically for this study, with private access and run by the researchers who invited the participants who were part of their personal contacts network. The ethical conditions, namely the guarantee of anonymity and confidentiality, were assured to the participants, using an informed consent form, signed by the participants' guardians when the students were underage, and the instrument was available online for completion (LimeSurvey tool).

The Statistical Package for Social Sciences-SPSS for Windows, version IBM24 was used for data analysis, assuming a 95\% confidence level in the nonparametric analyses (Mann Whitney U and Kruskal Wallis tests) performed.

\section{Findings}

The autonomy dimension with the highest score (Table 02) was the functional (3.74 \pm .59$)$, in total agreement with what had occurred in the validation study of the instrument for Portuguese population (Graça et al., 2010). The lowest score was obtained by the emotional dimension $(2.19 \pm 1.10)$.

Table 02. Autonomy perceived by adolescents/young people - Subscales and total of AQA

\begin{tabular}{|l|l|l|l|l|}
\hline AQA Subscales and Total & M & SD & Min. & Max. \\
\hline Functional autonomy & 3.74 & 0.59 & 2 & 5 \\
\hline Cognitive autonomy & 3.43 & 0.57 & 2 & 5 \\
\hline Emotional autonomy & 2.19 & 1.10 & 1 & 5 \\
\hline Overall autonomy & 48.50 & 8.60 & 30 & 75 \\
\hline
\end{tabular}

Note: M: Mean; SD: Standard Deviation; Min: Minimum; Max: Maximum

The lowest and highest scores (Table 03) were verified in Items 1 - I realize that I have a hard

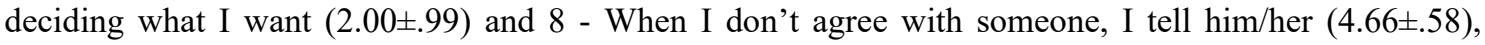
respectively.

Evidence showed that institutionalized adolescents/young people had higher levels of autonomy than those who were living with their families, both in overall autonomy $(U=109.5, p=.02)$ and in functional subscale $(U=119.0, p=.03)$. These results agree with literature. In fact, adolescents who experience contexts of greater social risk have higher levels of autonomy. In the case of the participants who were living in institutional care, we must take into account the work done to prepare their transition to independent adulthood. It seems that this work, in our sample, is producing good results, a situation that is highlighted in other studies (Clemente, 2013). These findings shouldn't be surprising given the crucial role played by these institutions in the process of empowering young people (Gomes, 2013).

Table 03. Autonomy perceived by adolescents/young people - Items of AQA

\begin{tabular}{|l|l|l|l|l|}
\hline AQA Items & M & SD & Min. & Max. \\
\hline 1. I realize I have a hard time deciding what I want & 2.00 & 0.99 & 1 & 5 \\
\hline $\begin{array}{l}\text { 2. When my actions go against someone else's opinion, I tend } \\
\text { to get nervous }\end{array}$ & 2.52 & 1.25 & 1 & 5 \\
\hline 3. I head straight to my goals & 4.32 & 0.88 & 2 & 5 \\
\hline 4. I can choose easily & 4.27 & 0.87 & 2 & 5 \\
\hline 5. I have a bad habit of giving in to other people's wishes & 2.26 & 1.15 & 1 & 5 \\
\hline 6. I often don't know what to think & 2.44 & 1.16 & 1 & 5 \\
\hline
\end{tabular}




\begin{tabular}{|l|l|l|l|l|}
\hline 7. It is hard for me to start an activity on my own & 2.41 & 1.16 & 1 & 5 \\
\hline 8. When I don't agree with someone, I tell him/her & 4.66 & 0.58 & 3 & 5 \\
\hline $\begin{array}{l}\text { 9. When people ask me what I want, I know exactly what to } \\
\text { answer }\end{array}$ & 4.00 & 1.22 & 1 & 5 \\
\hline 10. I can easily start different activities on my own & 4.15 & 1.04 & 1 & 5 \\
\hline 11. I often agree with the others, even when I'm not sure & 2.17 & 1.16 & 1 & 5 \\
\hline 12. I am a brave person & 4.55 & 0.75 & 2 & 5 \\
\hline $\begin{array}{l}\text { 13. I often change my mind after listening to the others' } \\
\text { opinions }\end{array}$ & 2.22 & 1.19 & 1 & 5 \\
\hline $\begin{array}{l}\text { 14. I adapt quickly and it is easy for me to feel comfortable in } \\
\text { a new situation }\end{array}$ & 4.23 & 1.02 & 2 & 5 \\
\hline 15. I often have doubts about what I should do & 2.31 & 1.02 & 1 & 5 \\
\hline
\end{tabular}

Gender was discriminatory: boys scored higher in the functional $(\mathrm{U}=86.5, \mathrm{p}=.03)$ and cognitive $(\mathrm{U}=86.5, \mathrm{p}=.04)$ autonomy dimensions, just as in the study conducted by Graça et al. (2010), for the first dimension, and in the research conducted by Gomes (2013), for the same subscales.

As for the two age groups (13 to 17 and 18 to 24 ), statistically significant differences were only found in functional autonomy ( $\mathrm{U}=119.0, \mathrm{p}=.03$ ), where younger had better results, contrary to what could be expected according to several studies (Graça et al., 2010). However, given the characteristics of our sample, highly representative of the female gender, the results are ultimately corroborated by the report of National Academies of Sciences, Engineering, and Medicine (2019), who found out that younger female adolescents develop autonomy issues more quickly than older male adolescents.

\section{Conclusion}

Understanding the demanding process of autonomy construction implies considering personal and contextual dimensions, as we aimed to analyse in this exploratory research project.

The better autonomy levels found in residential care participants stress the importance of investing in parental education, since evidence in our paper showed that staff in institutions seems able to deal with this adolescence developmental task of autonomy construction.

The relevance of socio-demographic variables in this process should also be highlighted, as they may represent clues to those responsible for designing interventions, that should be gender and age sensible. However, these results should be further empirical tested given the limitations of our study, namely the small sample size.

It is however important to keep investing in the professionals training as they play a key role in residential care ensuring that those adolescent's risk trajectory is effectively broken and that they may face an adequate transition to adulthood outside the institution, guided by their own autonomy and sense of responsibility.

\section{Acknowledgments}

Acknowledgment to the Centre for Studies in Education and Innovation, CI\&DEI - Polytechnic Institute of Viseu (IPV) for their financial support in paper translation. 


\section{References}

Bailey, C., Klas, A., Cox, R., Bergmeier, H., Avery, J., \& Skouteris, H. (2019). Systematic review of organisation-wide, trauma-informed care models in out-of-home care (OoHC) settings. Health Soc Care Community, 27(3), e10-e22. https://doi.org/10.1111/hsc.12621

Barbosa, P. V., Neumann, A. P., Alves, C. F., Teixeira, M. A. P., \& Wagner, A. (2017). Autonomia, Responsividade/Exigência e Legitimidade da Autoridade Parental: Perspectiva de Pais e Adolescentes. Psico-USF, 22(1), 23-34. https://doi.org/10.1590/1413-82712017220103

Bernal Romero, T., Melendro, M., \& Charry, C. (2020). Transition to Adulthood Autonomy Scale for Young People: Design and Validation. Frontiers in Psychology, 11, 457. https://doi.org/10.3389/fpsyg.2020.00457

Cabral, A. (2017). Do acolhimento à autonomização: Perceção dos jovens que viveram institucionalizados (Dissertação de Mestrado). Escola Superior de Educação de Coimbra e Escola Superior de Tecnologia da Saúde do Instituto Politécnico de Coimbra. http://biblioteca.esec.pt/cdi/ebooks/MESTRADOS_ESEC/ALCIDIA_CABRAL.pdf

Clemente,A. (2013). A transição para uma vida fora da instituição: Jovens a caminho da autonomia (Relatório de Mestrado). Faculdade de Psicologia e de Ciências da Educação da Universidade do Porto. https://repositorio- aberto.up.pt/bitstream/10216/69118/2/90868.pdf

Costa, A., Tomás, C., Luís, E., Rodrigues, L., Malheiro, M., \& Gonçalves, S. (2015). Autonomia: Desafios e práticas no acolhimento de jovens em instituição. https://content.gulbenkian.pt/wpcontent/uploads/2016/05/29202306/Brochura-Autonomia-Final-28_05.pdf

Delgado, P., \& Gersão, E. (2018). O acolhimento de crianças e jovens no novo quadro legal. Novos discursos, novas práticas? Análise Social, $\quad$ LIII(226), 112-134. https://doi.org/10.31447/as00032573.2018226.05

Del Valle, J., \& Quintana, G. (2006). Programa umbrella. Mirando al futuro con habilidades para vida [Umbrella program. Looking to the future with life skills]. ASACI.

Dutra-Thomé, L., Marques, L., Seidl-de-Moura, M. L., Ramos, D., \& Koller, S. (2019). Autonomy Development: Gender and Age Differences from Adolescence to Emerging Adulthood. Acta de Investigación Psicológica, 9, 14-24. https://doi.org/10.22201/fpsi.20074719e.2019.2.259

Graça, J., Calheiros, M., \& Martins, A. (2010). Adaptação do questionário de autonomia nos adolescentes (QAA)para a língua portuguesa. Laboratório de Psicologia, 8(2), 237-250. https://doi.org/10.14417/lp.644

Gomes, J.A. (2013). “Des” Institucionalização - Um processo's' de autonomia's [Institutional "Des" - A process of autonomy] (Master's Thesis). http://comum.rcaap.pt/handle/10400.26/8399

Instituto da Segurança Social (2018). CASA 2017-Relatório de caracterização anual da situação de acolhimento das crianças e jovens [CASA 2017- Annual characterization report on the situation of reception of children and young people]. http://www.segsocial.pt/documents/10152/16000247/Relatorio CASA 2017/537a3a78-6992-4f9d-b7a7$5 \mathrm{~b} 71 \mathrm{eb} 6 \mathrm{c} 41 \mathrm{~d} 9$

National Academies of Sciences, Engineering, and Medicine (2019). The Promise of Adolescence: Realizing Opportunity for All Youth. The National Academies Press. https://doi.org/10.17226/25388

Noom, M. (1999). Adolescent autonomy: Characteristics and correlates. Eburon.

Oliveira, L. (2016). Participação em colónias de férias e promoção da autonomia: Perceções de adolescentes e monitores [Participation in summer camps and promotion of autonomy: Perceptions of adolescents and monitors] (Master's Project). Escola Superior de Educação de Viseu. https://repositorio.ipv.pt/handle/10400.19/4493

Serdiuk, L., Danyliuk, I., \& Chaika, G. (2018). Personal autonomy as a key factor of human selfdetermination. Social Welfare: Interdisciplinary Approach, $1, \quad 85$. https://doi.org/10.21277/sw.v1i8.357

Seth-Purdie, R. (2019). Review of best practice in residential out of home care. Barton: UnitingCare Australia. http://unitingcare.org.au/wp-content/uploads/2019/09/Final-online-OOHC-report.pdf 
Sher-Censor, E. (2015). The challenges of Israeli adolescent girls: Gender differences in observed autonomy and relatedness in adolescent-mother interactions. Sex Roles: A Journal of Research, 72(3-4), 150-162. https://doi.org/10.1007/s11199-015-0445-5

Silva, A., Oliveira, K., \& Marques, C. (2019). Autonomização de jovens em acolhimento residencial: Discursos e significados. Configurações, 23, 14-30. https://doi.org/10.4000/configuracoes.7305

United Nations (1948). Universal Declaration of Human Rights. https://www.refworld.org/docid/3ae6b3712c.html

United Nations (1959). Declaration of the Rights of the Child. https://www.refworld.org/docid/3ae6b38e3.html

Wood, D., Crapnell, T., Lau, L., Bennett, A., Lotstein, D., Ferris, M., \& Kuo, A. (2018). Emerging Adulthood as a Critical Stage in the Life Course. In N. Halfon, C. B. Forrest, R. M. Lerner, \& E. M. Faustman (Eds.), Handbook of Life Course Health Development (pp. 123-143). Springer International Publishing. https://doi.org/10.1007/978-3-319-47143-3_7 